KILLER INST I NCT 



\title{
killer instinct
}

\author{
T H E
}

POPULAR SCIENCE

OF HUMAN NATURE

I N TWENTIETH -

CENTURY AMERICA

\section{Nadine Weidman}

\section{Harvard University Press}

Cambridge, Massachusetts \& London, England 2021 
Copyright (c) 2021 by the President and Fellows of Harvard College All rights reserved Printed in the United States of America

First printing

Cover texture: phongphans59222 / Getty Images

Cover design: Lisa Roberts

$$
\begin{gathered}
9780674269668 \text { (EPUB) } \\
9780674269651 \text { (PDF) }
\end{gathered}
$$

The Library of Congress has cataloged the printed edition as follows:

Names: Weidman, Nadine M., 1966- author.

Title: Killer instinct : the popular science of human nature in twentieth-century America/Nadine Weidman.

Description: Cambridge, Massachusetts : Harvard University Press, 2021. Includes bibliographical references and index.

Identifiers: LCCN 2021010914 | ISBN 9780674983472 (hardcover)

Subjects: LCSH: Science in popular culture-United States-History-20th century. |

Nature and nurture-United States-History-20th century. | Aggressiveness. | Sociobiology-United States-History-20th century. | Human behavior.

Classification: LCC Q172.5.P65 W45 2021 | DDC 306.4 /5-dc23

LC record available at https://lccn.loc.gov/2021010914 
To the memory of my beloved husband Joseph ANDrew Ferrari, JR.

September 25, 1965-December 15, 2020

$\diamond$

$$
\begin{aligned}
& \text { and to our children } \\
& \text { LEORA and ANDREW }
\end{aligned}
$$

this book is lovingly dedicated 
